\title{
Citrus Scion and Rootstock, Topping Height, and Tree Spacing Affect Tree Size, Yield, Fruit Quality, and Economic Return
}

\author{
T.A. Wheaton, J.D. Whitney, W.S. Castle, R.P. Muraro, H.W. Browning, and D.P.H. Tucker \\ University of Florida, IFAS, Citrus Research and Education Center, 700 Experiment Station Road, Lake \\ Alfred, FL 33850
}

Additional index words. high-density, tree density, tree size control, hedging

\begin{abstract}
A factorial experiment begun in 1980 included 'Hamlin' and 'Valencia' sweet-orange scions [Citrus sinensis (L.) Osb.], and Milam lemon (C. jambhiri Lush) and Rusk citrange [C. sinensis x Poncirus trifoliata (L.) Raf.] rootstocks, tree topping heights of 3.7 and $5.5 \mathrm{~m}$, between-row spacings of 4.5 and $6.0 \mathrm{~m}$, and in-row spacings of 2.5 and $4.5 \mathrm{~m}$. The spacing combinations provided tree densities of 370, 494, 667, and 889 trees ha. Yield increased with increasing tree density during the early years of production. For tree ages 9 to 13 years, however, there was no consistent relationship between yield and tree density. Rusk citrange, a rootstock of moderate vigor, produced smaller trees and better yield, fruit quality, and economic returns than Milam lemon, a vigorous rootstock. After filling their allocated space, yield and fruit quality of trees on Milam rootstock declined with increasing tree density at the lower topping height. Cumulative economic returns at year 13 were not related to tree density.
\end{abstract}

Citrus and other tree fruits yield more during the early years of production when planted at higher densities (Cary, 1981; Jackson, 1985; Patil, 1987). However, the advantage of higher densities at tree maturity is less certain. For citrus, we proposed that yield at maturity is independent of tree density over a range of densities (Wheaton et al., 1978). Production of modern mature apple orchards increased with tree density, however, possibly due to improved genetic material with a higher harvest index, rather than from higher tree density per se (Jackson, 198.5).

Production of citrus approaching $100 \mathrm{t} \cdot \mathrm{ha}^{-1}$ annually is a realistic goal and has been observed over a range of tree densities in several citrus production areas (Tablel; see Cary, 1981 for a review of earlier experiments). Production per ha while the plantings were young increased with increasing tree density in each of these experiments. Except for the California studies, production of 60 to $80 \mathrm{t} \cdot \mathrm{ha}^{-1}$ was obtained at the highest density in 4 to 6 years.

The experiments in Japan and Florida also provide evidence that yield at maturity is independent of tree density over a range of densities. In Japan, maximum annual production of 70 to $80 \mathrm{t} \cdot \mathrm{ha}^{-1}$ was similar for tree densities ranging from 1250 to 10,000 trees/ ha. Highest cumulative yield after 21 years was attained at 2500 trees/ha because yield at the highest densities declined over time. In Florida, maximum annual production of $100 \mathrm{t} \cdot h \mathrm{~h}^{-1}$ was similar for trees at 359 and 718 trees/ha, but was lower for trees at the lowest density of 215 trees/ha. Production was generally low in the California experiments and was not consistently related to tree density. The Australian report did not include data on production of the orchard at maturity. However, yield leveled or decreased very early at the higher densities due to intertree competition.

Vigorous trees rapidly fill their allocated space, but may be difficult to contain and may perform poorly in higher density plantings at maturity. A tree that grows rapidly to containment size

Received for publication 14 Nov. 1994. Accepted for publication 13 Apr. 1995. We greatly appreciate the cooperation and support of Coca Cola Foods Division, Auburndale, Fla. We also thank Jim Baldwin, Marjorie Cody, and David Noxel for their technical support. Florida Agricultural Experiment Station Journal Series no. 7241. The cost of publishing this paper was defrayed in part by the payment of page charges. Under postal regulations, this paper therefore must be hereby marked advertisement solely to indicate this fact. and then becomes less vigorous is desired. The range of dwarfing rootstocks used by apple growers to manipulate tree size and fruiting characteristics is not currently available to citrus growers. Although no satisfactory dwarfing rootstock for citrus is commercially available, citrus rootstocks do provide a modest range of tree vigor and final tree size (Castle et al., 1989). Another method of reducing vigor and tree size at maturity is the introduction of dwarfing citrus viroids into trees on susceptiblerootstocks (Hutton, 1986; Patil, 1987).

Citrus fruit quality is important for both fresh and processing markets. Reported effects of tree density on fruit quality are conflicting. Higher densities had little effect on fruit quality in the Japanese and Australian experiments, but was a major factor in the California studies. Only minor effects of tree density on fruit quality were observed in previous Florida experiments.

Financial evaluation of plantings for fruit production at various tree densities is essential. The relative costs of land, capital, and labor vary among citrus growing areas. Establishment expenses of a new planting and annual production costs vary with tree density. Discounted cash flow and the internal rate of return (IRR) were used to demonstrate the benefits of higher density plantings for apples (Jackson, 1985). Not all previous citrus spacing experiments included financial analyses. Where economic analyses were included, a relation between tree density and financial returns was present in some experiments but not in others (Boswell et al., 1975, 1982; Koo and Muraro, 1982; Wheaton et al., 1990).

The principal objective of our long-term experiment was to determine the combination of cultivar, rootstock, tree height, and

Table 1. Experimental citrus plantings include a wide range of tree densities.

\begin{tabular}{lccc}
\hline \hline Location & $\begin{array}{c}\text { Citrus } \\
\text { type }\end{array}$ & $\begin{array}{c}\text { Tree density } \\
\text { trees/ha }\end{array}$ & Reference \\
\hline Japan & Mandarin & $1250-10,000$ & Tachibana et al., 1987 \\
Australia & Orange & $667-5,000$ & Hutton, 1986 \\
California & Orange & $222-1,087$ & Boswell et al., 1975 \\
California & Orange & $331-801$ & Boswell et al., 1982 \\
Florida & Orange & $215-718$ & Koo and Muraro, 1982 \\
\hline
\end{tabular}


tree spacing which provided optimum financial returns over time for citrus grown in Florida's subtropical environment. Since financial analysis of previous experiments provided no basis for planting densities over 1000 trees/ha and because no satisfactory dwarfing rootstocks exist, tree densities from 370 to 889 trees/ha were selected for this study. Hypotheses included 1) yield increases with increasing tree density during the early years of a planting; 2) yield is independent of density at tree maturity; 3) rootstock vigor is an important factor in higher density plantings; 4) tree spacing has only minor effects on fruit quality, nutritional requirements, and pest and disease pressure at tree maturity; and 5) higher density plantings provide greater financial returns.

The initial results from this experiment confirmed the expected yield response to higher density during the first 2 years of production (Wheaton et al., 1986). Whitney et al. (1991) found water use and root concentration per unit of land area for 7- and g-year-old trees were similar for the lowest and highest tree densities. The effects of tree size and fruit distribution on harvesting and fruit handling were reported (Whitney et al., 1994). The information summarized here includes results from the time of planting in 1980 through 1993 when tree age was 13 years. The transition from a young to a mature planting of trees reaching containment size occurred during this period.

\section{Materials and Methods}

The experiment was designed and analyzed (analysis of variance) as a multiple split-plot experiment with four replications (Table 2). Plot size was four rows $\times$ seven trees with the center ten trees (two rows $\times$ five trees) used for data collection.

Treatment selection criteria. 'Hamlin' and 'Valencia' were chosen because they are the predominant early- and late-season orange cultivars and also differ somewhat in scion vigor. 'Valencia' also provides a unique challenge in pruning for tree size control since fruit is present all year. Bloom and fruit set of the new crop occur before harvest of the previous crop. Hedging or topping at any time of year has the potential for fruit loss.

Milam and Rusk were selected as rootstocks to represent a vigorous stock and one of moderate vigor. Milam is a lemon-type stock with the characteristic vigor of the rough lemon stock used for many years on the well-drained sandy soils of the Central Florida Ridge. Rusk citrange provides moderate vigor and a smaller tree size than Milam rootstock and is a minor commercial rootstock (Castle et al., 1989).

Tree heights of 3.7 and $5.5 \mathrm{~m}$ represent the range of tree heights commonly maintained in Florida citrus groves. The 3.7-m height provides less shading of adjacent rows and trees at that height can be sprayed and harvested more efficiently than taller trees. The 5.5$\mathrm{m}$ topping height is more typical of Florida citrus, however, and provides more canopy volume per ha with the corresponding potential for greater yield.

The $6.0-\mathrm{m}$ between-row spacing is the minimum commonly used in commercial plantings and provides adequate access for production and fruit handling machinery. The 4.5-m row spacing is the minimum width that can be managed using standard production equipment. Fruit handling using conventional equipment is quite difficult at this row spacing. Between-row spacing of most commercial plantings in Florida remains at about $7.5 \mathrm{~m}$.

In-row spacings of 2.5 and $4.5 \mathrm{~m}$ span the range commonly planted today in commercial Florida groves. Earlier studies demonstrated that hedgerows were optimal production systems for Florida citrus (Wheaton et al., 1984), and almost all Florida citrus trees are now planted to form a hedgerow at an early age.

The between-row and in-row spacings used in this experiment result in tree densities ranging from 370 to 889 trees/ha. By comparison, the average density of new plantings in Florida from 1990 to 1992 was 345 trees/ha (Freie and Gaskalla, 1992). Tree densities in this experiment ranged from slightly above the mean for new commercial plantings to about 2.5 times that level.

Site and management. The experiment, established in 1980 on a 10 ha site in Polk County, Fla., is located at latitude $27^{\circ} 47^{\prime} \mathrm{N}$ on an upland site. Most of the soil is excessively drained Candler sand with low organic matter content. The surface layer is typically 15 $\mathrm{cm}$ of dark brown sand underlain by $150 \mathrm{~cm}$ of brownish yellow that grades to yellow. About $50 \%$ of one replication is planted in Tavares fine sand, a deep but moderately well-drained soil. Trees

Table 2. Experiment factors, levels, and tree densities.

\begin{tabular}{lc}
\hline \hline Experiment design & Factor and level \\
\hline Main plot & Scion cultivar \\
& 'Hamlin' (early-maturing orange) Citrus sinensis (L.) Osb. \\
& 'Valencia' (late-maturing orange) C. sinensis \\
Subplot & Tree height \\
& $3.7 \mathrm{~m}$ \\
& $5.5 \mathrm{~m}$ \\
Sub-subplot & Between-row spacing \\
& $4.5 \mathrm{~m}$ \\
Sub-sub-subplot & $6.0 \mathrm{~m}$ \\
& Rootstock \\
& Milam lemon (vigorous) C. jambhiri Lush hybrid? \\
Sub-sub-sub-subplot & Rusk citrange (moderale vigor) C. sinensis X Poncirus trifoliata (L.) Raf. \\
& $2.5 \mathrm{~m}$ \\
Tree spacing & $4.5 \mathrm{~m}$ \\
\hline Between $\times$ in row & Trees/ha \\
$4.5 \times 2.5 \mathrm{~m}$ & 889 \\
$6.0 \times 2.5 \mathrm{~m}$ & 667 \\
$4.5 \times 4.5 \mathrm{~m}$ & 494 \\
$6.0 \times 4.5 \mathrm{~m}$ & 370 \\
\hline
\end{tabular}


were planted in north-south rows as part of a commercial grove. Standard production practices and harvesting equipment were used throughout the experiment. A permanent overhead sprinkler irrigation system was installed prior to planting the trees and provided uniform water application over the land area. A regular commercial young tree care program was followed for the first 3 years, which included fertilizing on an individual tree basis. Beginning with year 4, fertilizer and foliar pesticides were applied uniformly on a land area basis. Thus, trees at different spacings all received water, fertilizer, and pest management on a land area basis, not on a per tree basis.

Tree hedging and topping were begun as soon as necessary for tree size control. Annual hedging was begun in 1985 and 1986 for the 4.5- and 6.0-m between-row spacings, respectively. Hedging angle was 7" from vertical toward the top of the tree. Hedging width was set to maintain an open middle of $2.0 \mathrm{~m}$ until 1991 and $2.1 \mathrm{~m}$ thereafter. During most years, all trees were hedged in early spring, shortly after the 'Hamlin' but before the 'Valencia' harvest. Topping was also begun as soon as trees exceeded the targeted tree height. Annual topping was begun in 1987 and 1991 for the 3.7and 5.5-m heights, respectively. Beginning in 1991, trees at the 3.7-m height were topped in the spring and fall of each year in an attempt to reduce regrowth and improve fruiting of trees on Milam rootstock.

Measurements. Trunk diameter was measured annually from 1980 to 1991 and tree canopy was measured each spring beginning in 1986. Canopy volume was based on an equation derived by J.D. Whitney which is suitable for individual trees and partial or fully formed hedgerows:

$$
\mathrm{CV}=\pi / 4 * \mathrm{EW} * \mathrm{NS} * \mathrm{HT} *\left(1-\left(1-\left((\mathrm{HI} / \mathrm{HT})^{2}\right)\right) / 3\right)
$$

where $\mathrm{CV}=$ canopy volume per tree $\left(\mathrm{m}^{3}\right), \mathrm{EW}=$ canopy diameter in east-west direction $(\mathrm{m})$, NS = canopy diameter in north-south direction $(\mathrm{m}), \mathrm{HT}=$ tree height $(\mathrm{m})$, and $\mathrm{HI}=$ height of intercept between two adjacent trees (m); which is the maximum height where trees touch or grow together in the row.

Before trees touch in the row, $\mathrm{HI}=0$ and the equation reduces to the volume of one-half of an ellipsoid. The HI term allows estimation of canopy volume of partially or fully formed hedgerows.

Fruit yield was determined by harvesting and weighing the fruit from the center 10 trees of each plot until 1987-88, and five trees per plot thereafter, In case of a missing tree, yield was based on the number of trees present. Samples of 60 to 80 fruit were randomly collected from each plot during harvesting to determine average fruit size (weight per fruit), external fruit color, juice percent, soluble solids and acid concentrations, and color. Juice was extracted using standard automatic extraction and computerized test equipment found in Florida processing plants. External fruit color was measured using a Hunter Color Difference Meter, and juice color score was determined using a citrus calorimeter (Hunterlab D45-2; Hunter Associates Laboratory, Reston, Va.).

Tree nutritional status was determined annually. A 60-leaf sample from nonfruiting 6-month-old spring flush shoots was collected and analyzed for $\mathrm{N}, \mathrm{P}, \mathrm{K}, \mathrm{Ca}$, and $\mathrm{Mg}$ using standard

Table 3. Analysis of variance of factorial effects of citrus cultivar, topping height, between-row spacing, rootstock, and in-row spacing on tree size, yield, and fruit quality.

\begin{tabular}{|c|c|c|c|c|c|c|c|c|c|c|c|c|c|c|}
\hline & \multirow[b]{2}{*}{$\begin{array}{c}1991 \\
\text { Trunk } \\
\text { diam } \\
(\mathrm{cm}) \\
\end{array}$} & \multirow[b]{2}{*}{$\begin{array}{c}1993 \\
\text { Tree } \\
\text { ht } \\
(\mathrm{m})\end{array}$} & \multirow[b]{2}{*}{$\begin{array}{c}1993 \\
\text { Canopy } \\
\text { vol } \\
\left(\mathrm{m}^{3} \cdot \mathrm{ha}^{-1}\right)\end{array}$} & \multirow[b]{2}{*}{$\begin{array}{c}\text { 1984-93 } \\
\text { Cumul. } \\
\text { yield } \\
\left(\mathrm{t} \cdot \mathrm{ha}^{-1}\right)\end{array}$} & \multirow[b]{2}{*}{$\begin{array}{c}\text { 1984-93 } \\
\text { Cumul. } \\
\text { solids } \\
\left(\mathrm{t} \cdot \mathrm{ha}^{-1}\right)\end{array}$} & \multirow[b]{2}{*}{$\begin{array}{c}1984-88 \\
\text { Avg } \\
\text { yield } \\
\left(\mathrm{t} \cdot \mathrm{ha}^{-1}\right)\end{array}$} & \multirow[b]{2}{*}{$\begin{array}{c}1989-93 \\
\text { Avg } \\
\text { yield } \\
\left(\mathrm{t} \cdot \mathrm{ha}^{-1}\right)\end{array}$} & \multicolumn{7}{|c|}{ Avg 1991-93 } \\
\hline & & & & & & & & $\begin{array}{c}\text { Crop } \\
\text { efficiency } \\
\left(\mathrm{kg} \cdot \mathrm{m}^{-3}\right)\end{array}$ & $\begin{array}{c}\text { Fruit size } \\
\text { (g/fruit) }\end{array}$ & $\begin{array}{c}\text { Juice } \\
\text { content } \\
(\%)\end{array}$ & $\begin{array}{l}\text { Soluble } \\
\text { solids } \\
(\%)\end{array}$ & $\begin{array}{l}\text { Juice } \\
\text { acid } \\
(\%)\end{array}$ & $\begin{array}{l}\text { Fruit } \\
\text { color } \\
\text { ab }\end{array}$ & $\begin{array}{l}\text { Juice } \\
\text { color } \\
\text { score }\end{array}$ \\
\hline Cultivar (C) & NS & $*$ & ** & $* *$ & * & * & $* *$ & NS & $* *$ & $* *$ & $* *$ & $* *$ & $* *$ & $* *$ \\
\hline Height $(\mathrm{H})$ & NS & $* *$ & $* *$ & $* *$ & $* *$ & $*$ & $* *$ & $*$ & $*$ & $*$ & $*$ & NS & $* *$ & NS \\
\hline $\mathrm{C} \times \mathrm{H}$ & NS & $* *$ & $*$ & $*$ & NS & NS & * & NS & NS & NS & NS & NS & NS & NS \\
\hline Between-row (B) & $* *$ & NS & $* *$ & NS & $*$ & $* *$ & $* *$ & $* *$ & $* *$ & NS & $* *$ & $* *$ & NS & * \\
\hline $\mathrm{C} \times \mathrm{B}$ & NS & NS & NS & NS & NS & NS & NS & $*$ & NS & NS & NS & NS & NS & NS \\
\hline $\mathrm{H} \times \mathbf{B}$ & $*$ & NS & NS & NS & NS & NS & NS & NS & NS & $* *$ & NS & NS & NS & NS \\
\hline $\mathrm{C} \times \mathrm{H} \times \mathrm{B}$ & NS & NS & $* *$ & NS & NS & NS & NS & NS & NS & NS & NS & NS & NS & NS \\
\hline Stock (S) & $* *$ & . $* *$ & $* *$ & $* *$ & $* *$ & $* *$ & $* *$ & $* *$ & $* *$ & $* *$ & $* *$ & $* *$ & $* *$ & $* *$ \\
\hline $\mathrm{C} \times \mathrm{S}$ & NS & NS & NS & $* *$ & $* *$ & NS & $* *$ & $* *$ & $* *$ & $* *$ & NS & NS & NS & NS \\
\hline $\mathrm{H} \times \mathrm{S}$ & NS & $* *$ & $* *$ & $*$ & $*$ & NS & $* *$ & $*$ & $*$ & $* *$ & $* *$ & NS & NS & NS \\
\hline $\mathrm{B} \times \mathrm{S}$ & NS & NS & $* *$ & $* *$ & $* *$ & NS & $* *$ & $* *$ & NS & $*$ & NS & $*$ & NS & NS \\
\hline $\mathrm{C} \times \mathrm{H} \times \mathrm{S}$ & NS & $*$ & NS & $*$ & NS & NS & * & $*$ & NS & $* *$ & NS & $*$ & NS & NS \\
\hline $\mathrm{C} \times \mathrm{B} \times \mathrm{S}$ & NS & NS & NS & NS & $*$ & $*$ & NS & $*$ & NS & NS & NS & $*$ & NS & NS \\
\hline In-row (I) & $* *$ & $*$ & $* *$ & $* *$ & $* *$ & $* *$ & $*$ & $* *$ & NS & NS & $* *$ & $* *$ & NS & NS \\
\hline $\mathrm{C} \times \mathrm{I}$ & NS & NS & $* *$ & NS & NS & NS & $*$ & NS & NS & NS & NS & NS & $* *$ & NS \\
\hline $\mathrm{H} \times \mathrm{I}$ & NS & $*$ & NS & $* *$ & $*$ & NS & $* *$ & NS & NS & NS & NS & NS & NS & NS \\
\hline $\mathrm{B} \times \mathrm{I}$ & $*$ & NS & $* *$ & NS & NS & NS & $*$ & $*$ & NS & NS & NS & NS & NS & NS \\
\hline$S \times I$ & NS & $*$ & $* *$ & $* *$ & $* *$ & NS & $* *$ & NS & $* *$ & NS & $* *$ & NS & $* *$ & NS \\
\hline $\mathrm{C} \times \mathrm{H} \times \mathrm{I}$ & NS & $*$ & NS & NS & NS & NS & NS & NS & NS & NS & $*$ & NS & NS & NS \\
\hline $\mathrm{C} \times \mathrm{B} \times \mathrm{I}$ & $*$ & NS & NS & NS & NS & NS & NS & NS & NS & NS & NS & NS & NS & NS \\
\hline $\mathrm{C} \times \mathrm{S} \times \mathrm{I}$ & NS & $*$ & NS & $*$ & NS & NS & NS & NS & NS & NS & NS & NS & NS & NS \\
\hline $\mathrm{H} \times \mathrm{B} \times \mathrm{I}$ & NS & NS & NS & NS & NS & NS & NS & NS & NS & NS & NS & NS & NS & NS \\
\hline $\mathrm{H} \times \mathrm{S} \times \mathrm{I}$ & NS & $*$ & NS & $*$ & $* *$ & NS & $* *$ & $*$ & NS & NS & $*$ & NS & NS & NS \\
\hline $\mathrm{B} \times \mathrm{S} \times \mathrm{I}$ & NS & NS & $*$ & NS & NS & NS & NS & NS & NS & NS & NS & NS & NS & NS \\
\hline
\end{tabular}

NS, ${ }^{*} * *$ Nonsignificant or significant at $\mathrm{P}=0.05$ or 0.01 , respectively. 


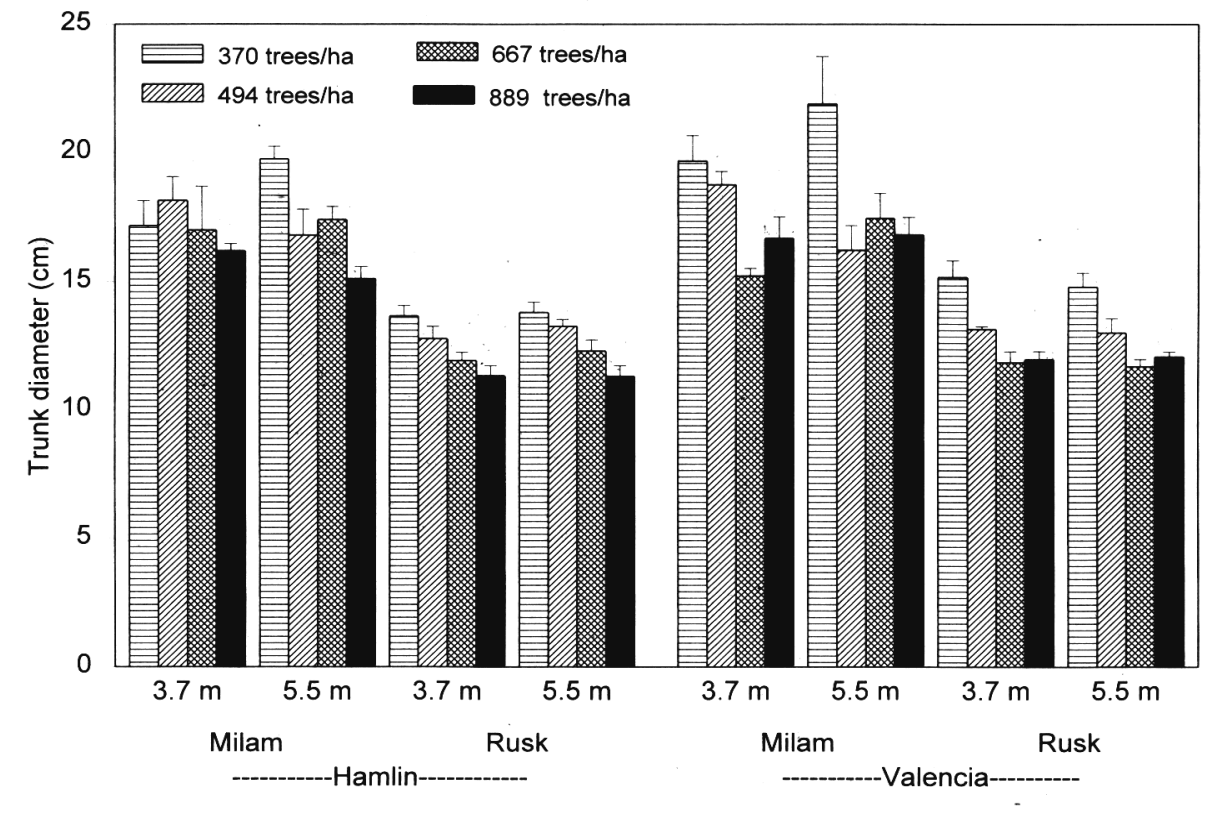

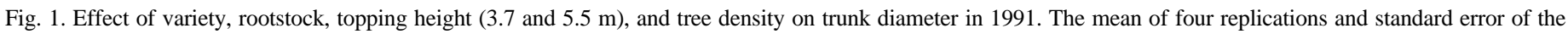
mean are shown.

procedures (Rhue and Kidder, 1984). Fertilizer was applied at recommended rates for Florida citrus and adjusted based on leaf analysis (Koo et al., 1984). Freeze damage was visually rated following freezes in 1983, 1985, and 1989. Pest intensity was monitored from 1990 through the 1992-93 season for 13 common citrus pests by direct timed pest census, destructive random sampling, and damage assessment methods.

Financial analyses. Financial analyses were based on annual discounted cash flow from the beginning of the experiment in 1980 through the 1992-93 season. Costs of each operation including trees, planting, production practices, etc., were average Florida costs for the year the expense was incurred. Similarly, returns were based on actual yield and average seasonal price for each cultivar. Annual discounted costs and returns used in calculation of the IRR included the following assumptions:

1) Historic production costs for each year.

2) Costs adjusted for planting density including initial tree purchase and planting as well as earlier hedging and a continuing differential for greater equipment travel distance per ha at the close; between-row spacing.

3) Seasonal delivered-in prices for juice soluble solids for both scion cultivars as reported by the Florida Processors Association.

4) Average seasonal harvesting costs for oranges.

5) Actual yields for each scion cultivar, topping height, rootstock, and spacing.

6) No tree loss from the original planting.

7) Interest on annual operating cost included, but no interest cost on capital investment of land value, land preparation, irrigation investment, and cost of trees and planting.
8) An investment return rate of $15 \%$ used to calculate the internal rate of return (IRR). The target $15 \%$ return rate represents an average historic rate for Florida orange groves producing fruit for processing.

\section{Results}

The treatment factors resulted in many significant differences and interactions (Table 3). Some of the main effects and interactions are easily explained and result from known differences among cultivars and rootstocks. Because of the large number of significant interactions, means for all factor combinations are presented as bar charts in Figs. 1-9. The bars in these figures are ordered by tree density rather than by between-row and in-row spacings. Reference to Table 2 provides the corresponding tree spacing for each tree density.

Tree size. Trunk diameter in 1991 (Fig. 1) was larger for trees on Milam rootstock than for trees on Rusk and was smaller with increasing tree density. This effect of tree density on trunk diameter was observed 4 years after planting (Wheaton et al., 1986), indicating very early competition among trees at the closer spacings.

Trees on Milam were vigorous and reached the 3.7- and 5.5- $\mathrm{m}$ topping height by 1987 and 1991, respectively. Initial growth of trees on Rusk was also vigorous, and most trees were at or near the $3.7-\mathrm{m}$ topping height by 1987 . Tree vigor declined as the trees matured, however, and no trees reached topping height in the 5.5$\mathrm{m}$ plots. Trees in the $5.5-\mathrm{m}$ plots grew very little during the last 5 years, and are similar in size to the trees in the plots topped at 3.7$\mathrm{m}$. This difference in tree height between Milam and Rusk in the $5.5-\mathrm{m}$ plots is reflected in the height $\times$ stock interaction which is significant for several variables. Topping height strongly influenced yield and fruit quality of trees on Milam, but had little effect on trees with Rusk rootstock.

Annual topping at the 3.7-m height of trees on Milam resulted in regrowth of 1 to $1.5 \mathrm{~m}$ each year and reduced fruiting. Topping in both late spring and fall was begun in 1991 in an effort to provide better vegetative control. These trees remained excessively veg- 


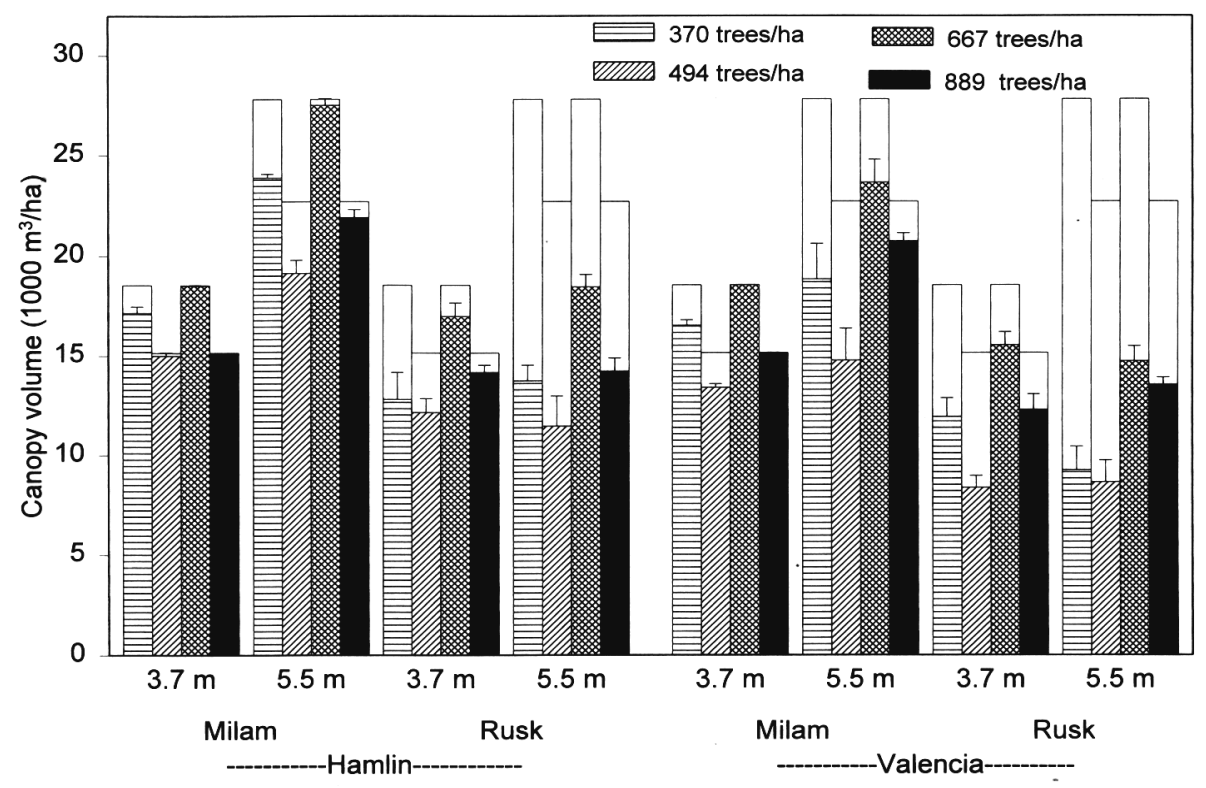

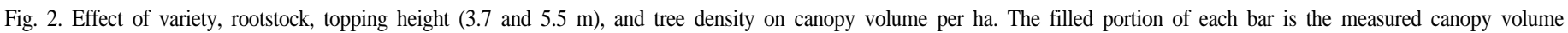
in 1993. Total bar height shows the maximum possible canopy volume when trees have fully reached planned containment size. The mean of four replications and standard error of the mean are shown.

etative under this topping schedule. Vigor of trees on Milam topped at $3.7 \mathrm{~m}$ resulted in poor production and fruit quality.

Canopy volume per ha was affected by cultivar, topping height, rootstock, and tree spacing (Fig. 2). 'Hamlin' trees on Milam at both the 3.7- and 5.5-m heights filled most of their allocated space, and 'Valencia' trees on Milam also approached containment size. Canopy volume of trees on Rusk was similar for the 3.7- and 5.5$\mathrm{m}$ topping heights because trees failed to reach the 5.5-m height. 'Hamlin' trees were slightly larger than 'Valencia' trees on Rusk rootstock.

Yield. Cumulative yield was affected by cultivar, topping height, rootstock, and spacing, with a number of significant interactions (Fig. 3). Interactions involving topping height and rootstock were expected based on rootstock effects on tree size. Cumulative yield of 'Hamlin' was greater than 'Valencia', and trees on Rusk produced slightly more than trees on Milam. Cumulative yield for trees on Milam decreased with increasing tree density at the 3.7-m topping height but was similar for all densities topped at $5.5 \mathrm{~m}$. Cumulative yield of trees on Rusk rootstock tended to increase with increasing tree density at both topping heights.

Yield expressed as cumulative soluble solids per hectare (Fig. 4) was affected by many of the same factors as cumulative yield. However, the advantage of Rusk rootstock is more apparent because of the higher soluble solids content of fruit from trees on Rusk.

Average annual yield for the first 5 years of production (1984-88) increasedsubstantially with increasing tree density (Fig. 5). Effects of rootstock and tree height, although significant, were small compared to the tree density effect on yield. Average annual yield for the second 5 years of production (1989-93) did not show a consistent response to tree density (Fig. 6). For this period, each rootstock must be considered separately. Trees on Milam stock and topped at the 3.7-m height performed poorly after filling their allocated space. The high vigor of this stock resulted in excessive vegetative growth and declining yield. Trees on Milam at the 5.5- $\mathrm{m}$ topping height continued to perform satisfactorily, however. Trees on Rusk rootstock produced well at all tree spacings. These 5-year average annual yields for 1989-93 of approximately 80 teha-' for 'Hamlin' and 60 t.hat ${ }^{-1}$ for 'Valencia' on Rusk rootstock were well above Florida averages.

Cropping efficiency expressed as fruit weight per unit of canopy volume (Fig. 7) was much higher for trees on Rusk than for trees on Milam. Cropping efficiency decreased with increasing tree density for trees on Milam at the 3.7-m topping height. For trees on Rusk stock, cropping efficiency was not related to overall tree density, but varied with between-row and in-row spacing. Cropping efficiency was lower for the greater between-row spacing (370 and 667 trees/ha) but was higher for the greater in-row spacing (370 and 494 trees/ha).

Fruit size and quality. Average fruit size and quality for the 1990-9 1 to 1992-93 seasons were used because weather and crop load were typical. Fruit size and quality were affected by several experimental factors and there were significant interactions. Many of the interactions resulted from expected cultivar and rootstock effects and from poor cropping and excessive vegetative growth of the trees on Milam rootstock topped at $3.7 \mathrm{~m}$.

Fruit size was larger for 'Valencia' than for 'Hamlin', and was larger for trees on Milam than trees on Rusk (data not shown). These effects correspond to effects of crop load on fruit size. Fruit size was not directly related to tree density, but was influenced by between-row spacing. Fruit was slightly larger for the closer between-row spacing (494 and 889 trees/ha) than for the wider between-row spacing (370 and 667 trees/ha).

External fruit color of 'Valencia' fruit was better than 'Hamlin', and fruit color from trees on Rusk rootstock was better than from trees on Milam (Fig. 8). Fruit color became poorer with increasing tree density for both cultivars on Milam stock at the 3.7-m topping height but there was no negative effect of increasing density for Rusk rootstock. Juice color was better for 'Valencia' than for 'Hamlin' juice (color score 35.6 and 33.2, respectively), and was slightly higher for trees on Rusk than for trees on Milam (color score 35.6 and 35.4 , respectively).

Juice content was higher for fruit from 'Valencia' trees and for 


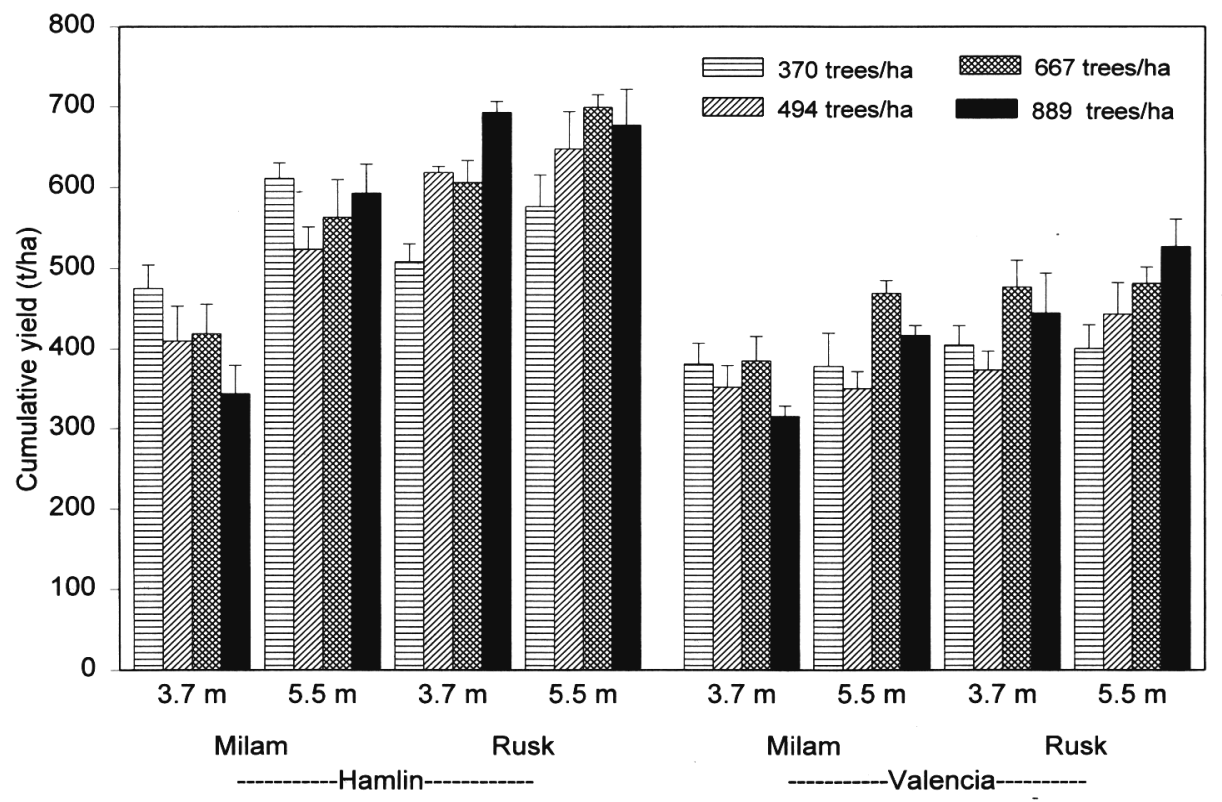

Fig. 3. Effect of variety, rootstock, topping height (3.7 and $5.5 \mathrm{~m}$ ), and tree density on cumulative fruit production (1980-93). The mean of fourreplications and standard error of the mean are shown.

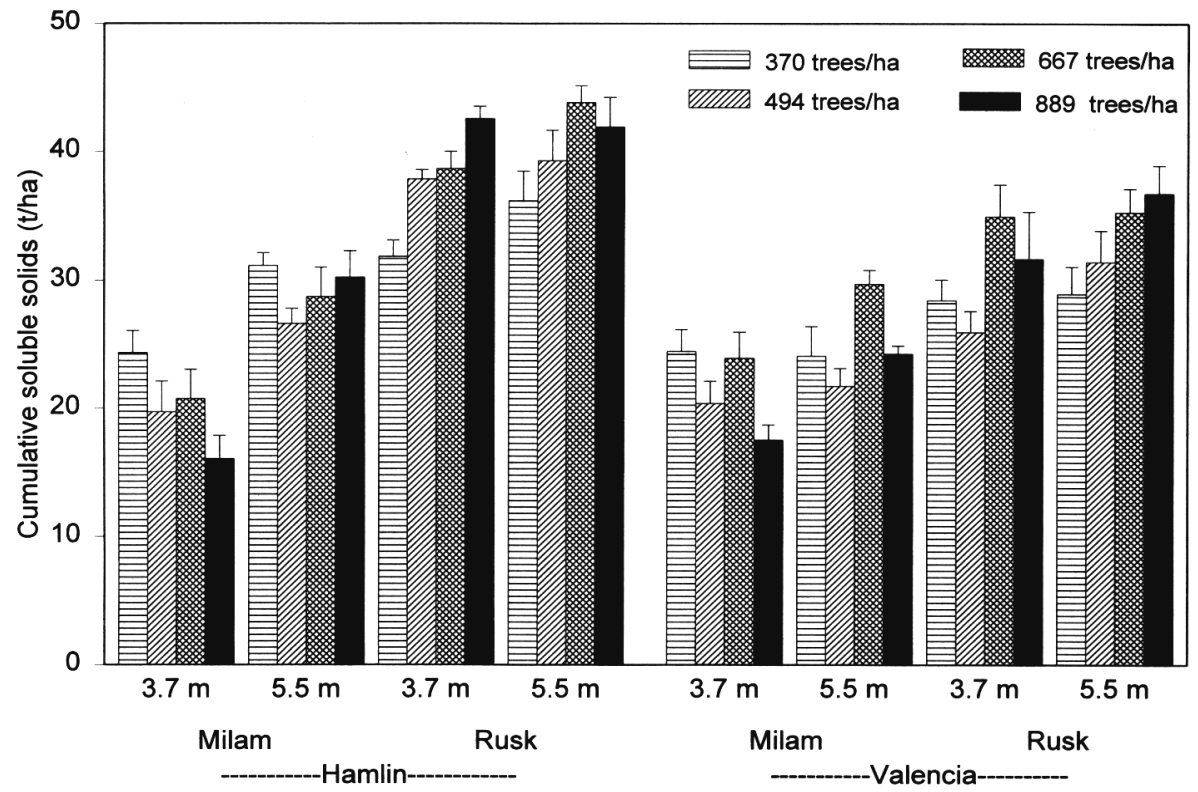

Fig. 4. Effect of variety, rootstock, topping height (3.7 and $5.5 \mathrm{~m}$ ), and tree density on cumulative production of soluble solids (1980-93). The mean of four replications and standard error of the mean are shown.

'Hamlin' trees on Ruskrootstock. Lowerjuice content for 'Hamlin' fruit on Milam stock was most apparent at the 3.7-m topping height.

The soluble solids concentration of juice was substantially higher for 'Valencia' fruit than for 'Hamlin' and was higher for fruit from trees on Rusk than for trees on Milam rootstock. There was no consistent trend with tree density, but juice soluble solids was affected by both between-row and in-row spacing. Soluble solids concentration was higher for trees at the wider between-row spacing (370 and 667 trees/ha) and was slightly higher for trees at the closer in-row spacing (667 and 889 trees/ha).

Juice acidity was higher for 'Valencia' fruit than for 'Hamlin', and was higher for fruit from trees on Rusk than for trees on Milam. Once again, there was no trend with tree density, but juice acidity was affected by both between-row and in-row spacing. Juice acidity was higher for trees at the greater between-row spacing and for trees at the closer in-row spacing. The soluble solids to acid ratio of the juice was higher for trees on Rusk than for trees on Milam, but this ratio was similar for both cultivars, tree heights, between-row and in-row spacings (means not shown).

Nutrition, diseases, pests, and tree loss. Leaf mineral nutrient content was generally in the optimum range and effects of tree density were minor. However, leaf $\mathrm{K}$ of trees on Rusk was in the deficient range in heavy crop years. These low $\mathrm{K}$ levels and associated fruit creasing were corrected by increasing $\mathrm{K}$ application by $25 \%$ relative to $\mathrm{N}$ during 1989 and 1990 . Pest intensity remained low during 3 years of monitoring and did not reach an economic threshold or cause significant fruit damage. Trees lost 
from freeze damage early in the experiment were replaced. A few trees have been removed due to citrus tree blight, a disease of unknown etiology. Possible movement of blight by root grafting (Tucker et al., 1984) is a concern in higher density plantings.

Financial analyses. The IRR after the 1992-93 season ( 13 years after planting) varied from $<0 \%$ to $20 \%$ (Fig. 9). It included discounted costs and returns for each year since the beginning of the experiment. The IRR of trees on Milam, which were topped at $3.7 \mathrm{~m}$, was low and decreased with increasing tree density. Trees on Milam provided better IRRs with 'Valencia' than with 'Hamlin' . The best IRRs were obtained from trees on Rusk, with both 'Hamlin' and 'Valencia' providing an IRR of over 15\%. There was no consistent effect of tree density on the IRR. The higher IRR observed in some cases for trees at the $6.0 \mathrm{~m}$ between-row spacing may reflect lower costs of establishing and maintaining trees at this row spacing. The relative insensitivity of IRR to tree densities ranging from 370 to 889 trees/ha, however, is the most important result.

\section{Discussion}

Yield increases with increasing tree density during the early years of a planting. Evidence exists for better early yield in higher density plantings from many experiments with citrus and other tree fruits. Yield in this study clearly increased with tree density during the first 5 years of production (Fig. 5). The length of time increased production will result from higher density depends on the time required for the trees to mature, or fill most of their allocated space. This, in turn, will depend on tree vigor, management practices, soil, climate, and the range of densities being compared. For example, benefits from higher density will last longer in a comparison of 150 and 300 trees/ha than in a comparison of 300 and 600 trees per ha, and longer in a cooler climate than a subtropical environment.

Data from the experiments in Japan, Australia, and Florida were combined in Fig. 10 to demonstrate the universal relationship between tree density and early productivity. Cumulative yield over the first 9 years for all tree densities in several experiments is plotted against tree density. This cumulative 9 -year yield increases rapidly as density increases from low to moderate, but the rate of increase diminishes substantially above 1000 trees/ha. Higher densities may be justified in cool climates or where dwarfing viroids are used. In Florida, rapid canopy development limits the advantage of higher density plantings to a relatively short time.

Yield is independent of density at tree maturity. Evidence exists for this hypothesis from this and other experiments with citrus. Yield during the second 5 years of production (mature trees) was similar (Fig. 6) for all tree densities (except for trees on Milam rootstock). Yield potential in Japan, Australia, and Florida was explicitly related to canopy development and, thus, to light interception. In Japan, yield per ha over time was expressed as a function of percent of land covered by canopy and of leaf area index (LAI). Maximum yield was reached at $80 \%$ to $100 \%$ canopy cover with a LAI of 6 to 7. In Australia, yield was evaluated as a function of canopy surface area. Production was maximum when the ratio of canopy surface area to ground area was 2 . This canopy surface area index of 2, obtained for tree densities up to 5000 trees/ ha, is the same value calculated for mature Florida plantings at much lower tree densities of 120 to 550 trees/ha. The effects of orchard design and planting density on light interception are welldocumented (Jackson, 1985). Light interception and yield potential of a mature planting appear to be similar over a wide range of tree densities. Thus, yield per hectare at complete canopy develop- ment should be independent of density per se unless higher densities are associated with a better harvest index.

In the present experiment, total canopy volume per hectare varied somewhat with spacing and other factors (Fig. 2). Cropping efficiency expressed as $\mathrm{kg}$ fruit $/ \mathrm{m}^{3}$ of canopy varied over a $1 \mathrm{O}$-fold range. Efficiency was higher for trees on Rusk rootstock than for trees on Milam. For trees on Rusk, cropping efficiency was higher for the closer between-row spacing but lower for the closer in-row spacing. It is noteworthy that yield per ha at maturity was similar over a range of cropping efficiencies. It appears cropping efficiency responds to a range of densities to maintain nearly constant production on a land area basis.

Rootstock vigor is an important factor in higher density plantings. Evidence for this hypothesis is strong. Initially, trees on both rootstocks grew rapidly and produced well through 1988 (Fig. 5). After this time, however, problems with the vigorous rootstock became apparent as trees on Milam at the 3.7-m topping height and higher densities performed poorly (Fig. 6). After trees reached containment size, the excessive vigor of this stock was detrimental because vegetative growth was excessive and yield declined. 'Valencia' orange, somewhat less vigorous than 'Hamlin' when grown on Milam or other rootstocks, was less adversely affected by higher density. Production of both cultivars on Milam topped at $5.5 \mathrm{~m}$ was satisfactory. At that topping height, yield of trees on Milam was less affected by tree density.

Trees on Rusk continued to perform well as they matured (Fig. 6). Production fluctuated from year to year, but average yield for the last several years was similar for all spacings. Hedging and topping requirements were minimal, and fruit distribution on the tree facilitated harvesting. The small tree size and non-thrifty appearance of trees on Rusk may account for lack of popularity of this stock. Rusk would be unsatisfactory at the wide spacings used in prior evaluations, but appears to be well-suited as a rootstock for plantings at the tree spacings used in this experiment. The moderate tree size and heavy fruiting density make it attractive for either hand or mechanical harvesting.

Tree spacing has minor effects on fruit quality. This hypothesis appears to be true also. Fruit quality was superior for the 'Valencia' cultivar and for the Rusk rootstock, as expected. Tree density and topping height had only minor effects on fruit size, fruit color, or juice characteristics of trees on Rusk rootstock. Fruit quality decreased, however, with increasing tree density for trees on Milam stock topped at $3.7 \mathrm{~m}$. This decrease in quality resulted from the excessive vigor, poor cropping, and a more juvenile character of this vigorous rootstock when tree size was too confined. The quality of 'Hamlin' fruit was more adversely affected by crowding than 'Valencia' fruit.

There were small effects of between-row and in-row spacing on juice soluble solids and acid content. Juice soluble solids and acid content were higher for the $6.0-\mathrm{m}$ between-row spacing than for the 4.5-m row spacing and in-row spacing had the opposite effect. Soluble solids and acid content of juice were negatively correlated with cropping efficiency (data not shown). This negative correlation may explain the effects of spacing on juice soluble solids noted above; i.e., higher soluble solids occurred where the number of fruit per unit of canopy volume was lower.

Effects of tree density on fruit quality in other experiments were generally small. In Japan, high fruit quality was maintained when canopy cover of the ground was maintained at $80 \%$ by suitable tree thinning and with fruit production of $60 \mathrm{t} \cdot \mathrm{ha}^{-1}$ (Tachibana and Nakai, 1989). Hutton (1986) in Australia found no effect of planting density up to 5000 trees/ha on fruit quality. Reduction in fruit quality, however, was a major concern in the California 


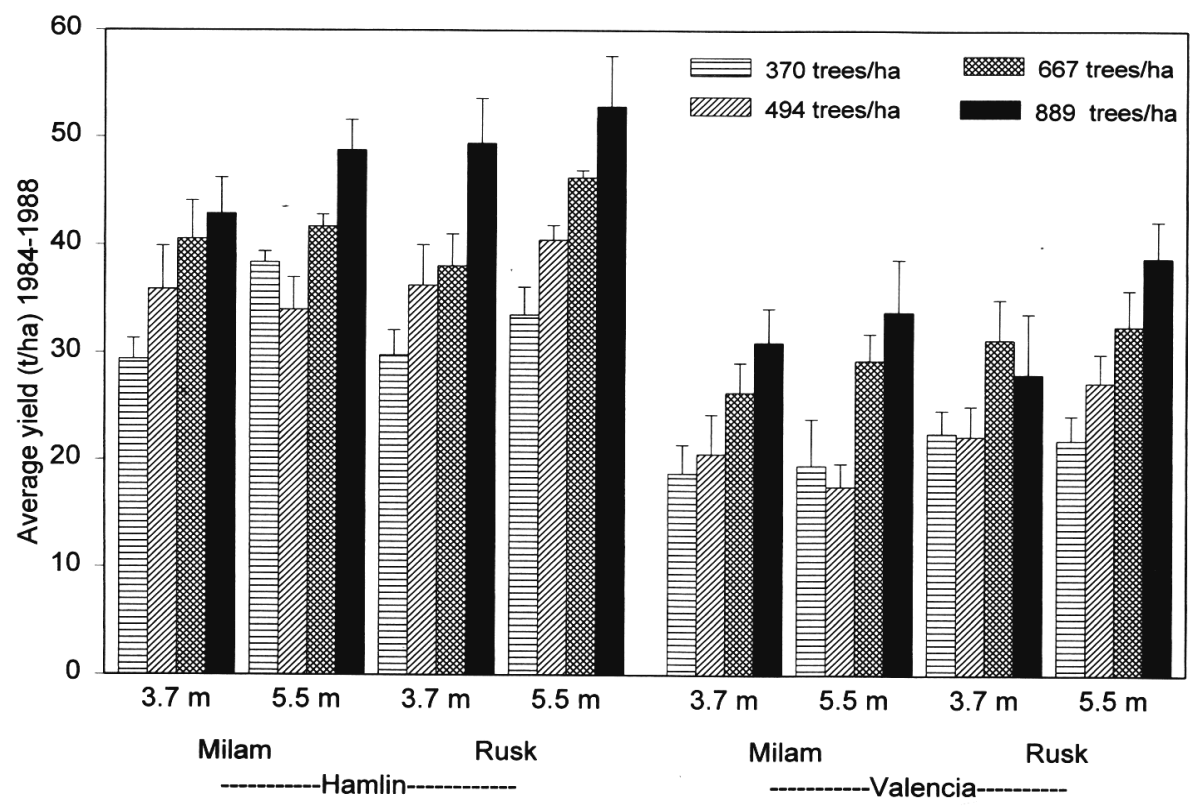

Fig. 5. Effect of variety, rootstock, topping height $(3.7$ and $5.5 \mathrm{~m}$, and tree density on average annual yield during the first 5 years of commercial production (198488). The mean of four replications and standard error of the mean are shown.

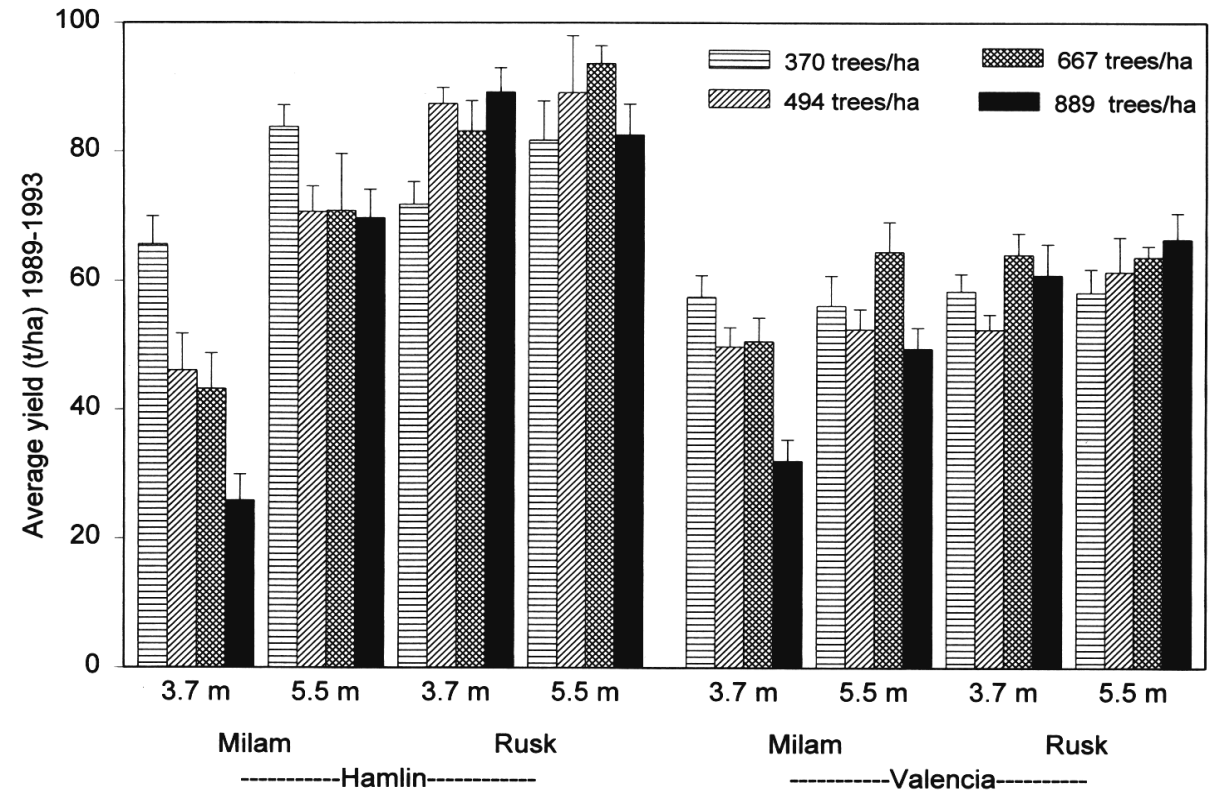

Fig. 6. Effect of variety, rootstock, topping height $(3.7$ and $5.5 \mathrm{~m})$, and tree density on average annual yield during the second 5 years of production (1989-93). The mean of four replications and standard error of the mean are shown.

studies, and the reason for including tree thinning treatments (Boswell et al., 1982). The Florida experiments indicate little effect of planting density on fruit quality, although this view is frequently contested by growers. The effects of tree density and direct fruit exposure to the sun on fruit quality appear to be much less important for citrus than for apple production.

Higher density plantings provide better-financial returns. Financial returns were relatively insensitive to tree densities in the range used in this experiment. The exception was a decline in IRR with increasing tree density for trees on Milam rootstock topped at $3.7 \mathrm{~m}$. Only trees on Rusk, which were well adapted to the planting densities used, will be considered in the rest of this discussion. Greater yield at higher densities during the first 5 years of produc- tion was in large part offset by higher establishment costs. Expenses for the first 4 years in the grove were $52 \%$ higher for 889 than for 370 trees per ha. Most additional expenses at the higher densities resulted from the cost of trees and tree planting. However, traveldistance per hectare is $25 \%$ less for the $6.0-\mathrm{m}$ than for the 4.5 $\mathrm{m}$ between-row spacing, which resultedin continuing higher costs for spraying and pruning at the closer row spacing.

An earlier experiment showed only a small financial difference between 351 and 718 trees/ha, but a substantial advantage of these densities compared to 215 trees/ha (Koo and Muraro, 1982). Another Florida planting at 2020 trees/ha provided no financial incentive for planting densities above 1000 trees/ha. Net return in the California navel experiments varied, and 


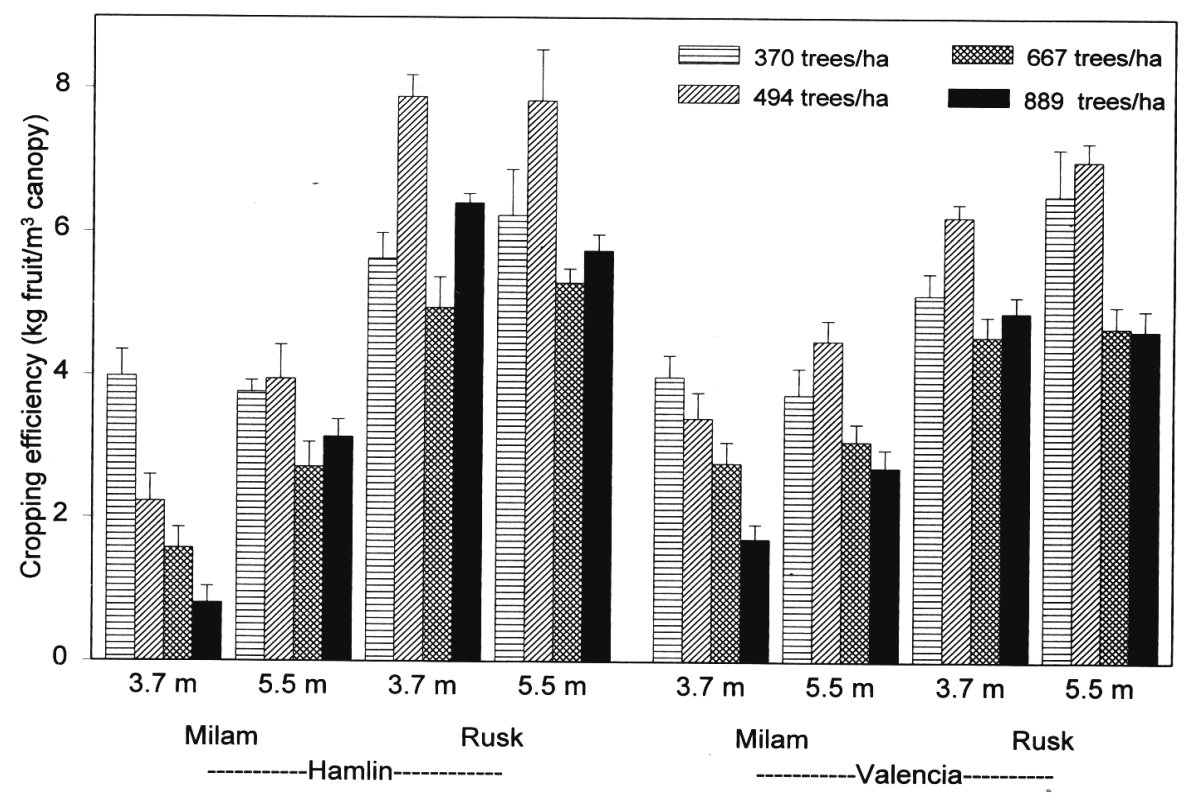

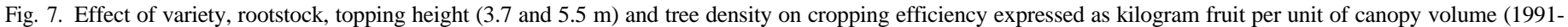
93). The mean of four replications and standard error of the mean are shown.

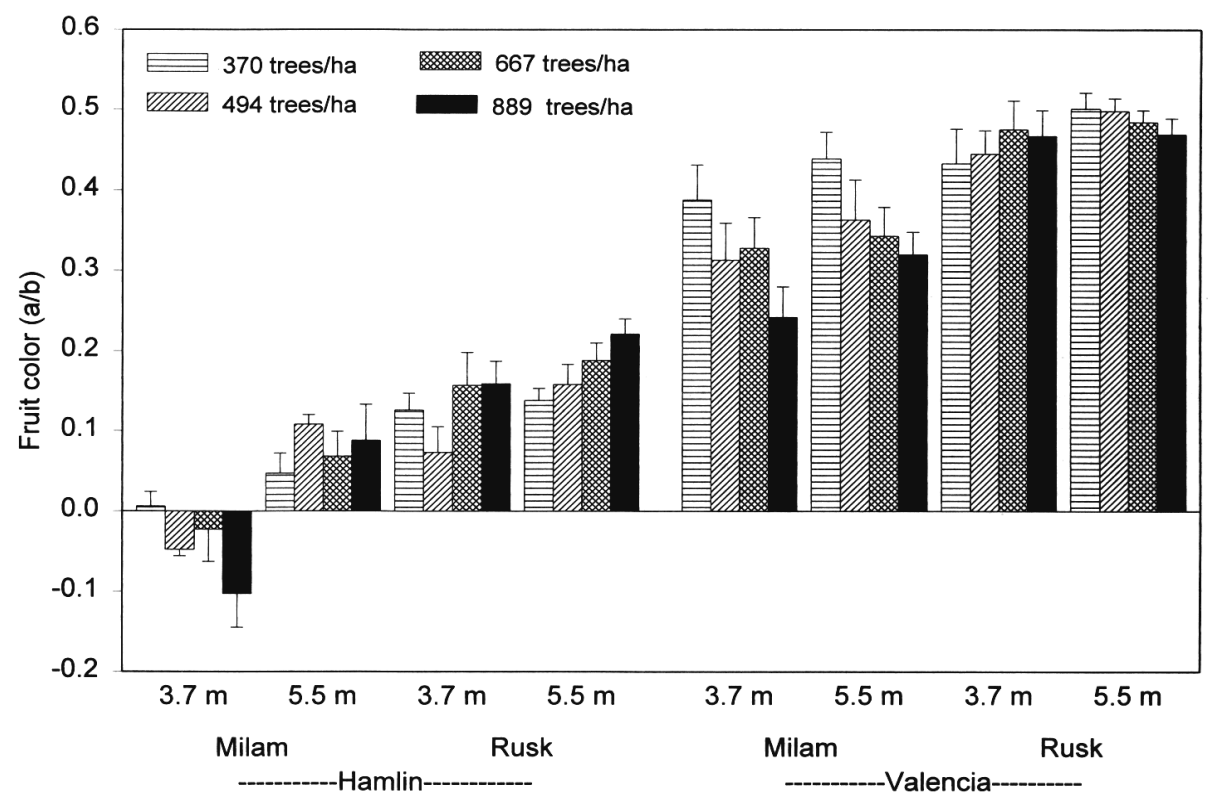

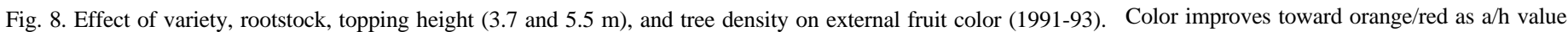
increases. The mean of four replications and standard error of the mean are shown.

higher density improved returns in one experiment (Boswell et al., 1982). Unfortunately, no financial analyses were provided for the much higher densities used in the Australian and Japanese experiments. The high densities used commercially in Japan suggest a financial advantage, but this benefit may be unique to their climate, small land holdings, use of tree thinning, and intensive management.

\section{Conclusions}

Because financial returns were relatively insensitive to the levels of most factors included in this experiment, various combinations of scion, rootstock, topping height, and tree spacing may be considered for new plantings. The planting arrangement must provide 20,000 to $30,000 \mathrm{~m}^{3}$ of canopy/ha, however, or canopy volume may limit yield. Tree vigor must be appropriate for the allocated tree space. Vigorous combinations of scion and rootstock cannot be successfully managed as small trees by topping and hedging. Planting densities in the range of 350 to 1000 trees/ha should be considered in Florida, using lower densities for more vigorous combinations. There is little reason to consider densities greater than 1000 trees/ha based on currently available rootstocks and today's costs and returns. Changes may occur, however, if improved genetic material becomes available or if tree design requires modification to facilitate or reduce the costs of manual or mechanical harvesting. 


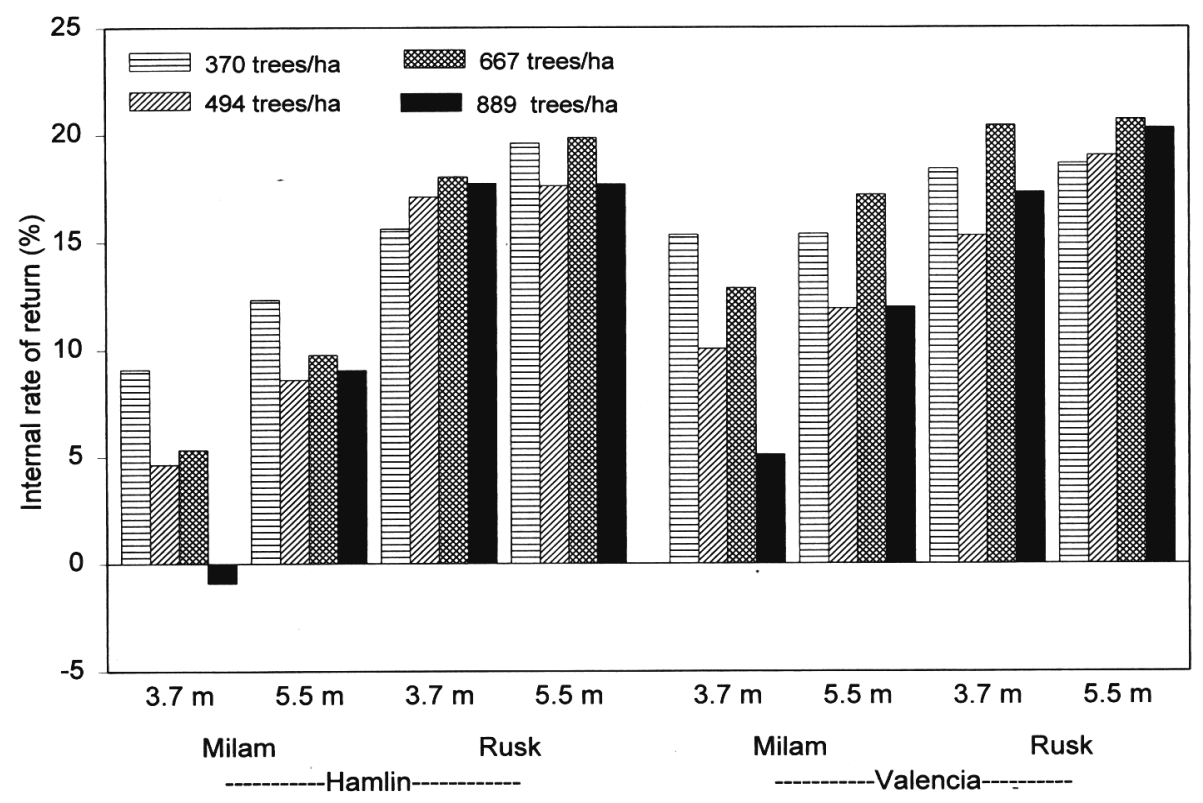

Fig. 9. Effect of variety, rootstock, topping height (3.7 and $5.5 \mathrm{~m})$, and tree density on financial returns calculated as the internal rate of return (IRR) (1980-93).

\section{Literature Cited}

Boswell, S.B., C.D. McCarty, K.W. Hench, and L.N. Lewis. 1975. Effect of tree density on the first ten years of growth and production of 'Washington' navel orange trees. J. Amer. Soc. Hort. Sci. 100:370-373.

Boswell, S.B., E.M. Nauer, and D.R. Atkin. 1982. Performance of navel oranges at six different spacings. Citrograph 67:207-212.

Cary, P.R. 1981. Citrus tree density and pruning practices for the 21st century. Proc. Intl. Soc. Citricult. 1:165-168.

Castle, W.S., D.P.H. Tucker, A.H. Krezdom, and C.O. Youtsey. 1993. Rootstocks for Florida citrus. 2nd ed. Univ. Fla., IFAS, Bul. SP42.

Freie, R.L. and R.D. Gaskalla. 1992. Commercial citrus inventory 1992. Fla. Agr. Stat. Serv., 1222 Woodward St., Orlando.

Hutton, R.J. 1986. The influence of tree size control and plant density on citrus productivity. Acta Hort. 175:249-254.

Jackson, J.E. 1985. Future fruit orchard design: Economics and biology, p. 441459. In: M.G.R. Cannell and J.E. Jackson (eds.). Attributes of trees as crop plants.

Koo, R.C.J., C.A. Anderson, I. Stewart, D.P.H. Tucker, D.V. Calvert, and H.K Wutscher. 1984. Recommended fertilizer and nutritional sprays for citrus. Univ. Florida Agr. Expt. Sta. Bul. 536D.

Koo, R.C.J. and R.P. Muraro. 1982. Effect of tree spacing on fruit production and net returns of 'Pineapple' oranges. Proc. Fla. State Hort. Soc. 95:29-33.

Patil, V.K. 1987. High density planting and dwarf rootstocks in citrus-A review. J. Maharashtra Agr. Univ. 12(2):189-194.

Rhue, R.D. and G. Kidder. 1984. Procedures used by the IFAS extension soil testing laboratory and interpretation of results. Univ. Fla. Ext. Circ. 596.

Tachibana, S., S. Morioka, and S. Nakai. 1987. Effect of planting density on fruit yield under different cultural treatments in Satsuma mandarin tree. J. Jpn. Soc. Hort. Sci. 56:9-15.

Tachibana, S. and S. Nakai. 1989. Relationship between crown density, yield, and leaf area index in different planting densities in Wase satsuma mandarins (Citrus unshiu Marc. var. praecox Tanaka). J. Jpn. Soc. Hort. Sci. 58:91-96.

Tucker, D.P.H., R.F. Lee, L.W. Timmer, L.G. Albrigo, and R.H. Brlansky. 1984. Experimental transmission of citrus blight. Plant Dis. 68:979-980.

Wheaton, T.A., W.S. Castle, D.P.H. Tucker, and J.D. Whitney. 1978. Higher density plantings for Florida citrus-Concepts. Proc. Fla. State Hort. Soc. 9 1:2733.

Wheaton, T.A., W.S. Castle, J.D. Whitney, D.P.H. Tucker, and R.P. Muraro. 1990. A high density citrus planting. Proc. Fla. State Hort. Soc. 103:55-59.

Wheaton, T.A., J.D. Whitney, W.S. Castle and D.P.H. Tucker. 1986. Tree spacing and rootstock affect growth, yield, fruit quality, and freeze damage of young 'Hamlin' and 'Valencia' orange trees. Proc. Fla. State Hort. Soc. 99:29-32.

Wheaton, T.A., J.D. Whitney, D.P.H. Tucker, and W.S. Castle. 1984. Cross hedging, tree removal, and topping affect fruit yield and quality of citrus hedgerows. Proc. Intl. Soc. Citricult. 1:109-114.

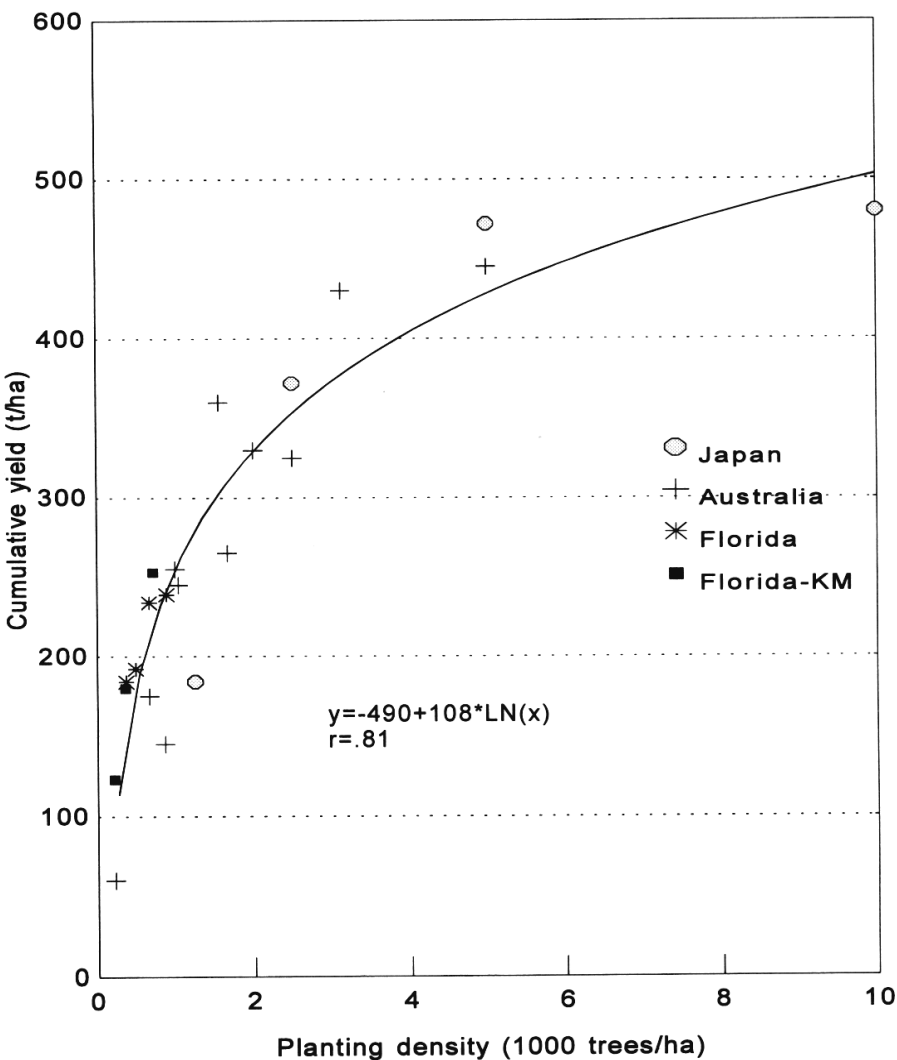

Fig. 10. Cumulative yield per hectare for the first 9 years of citrus planted at a wide range of tree densities. Experiments are Japan (Tachibana et al., 1987), Australia (Hutton, 1986), Florida (this study), and Florida-KM (Koo and Muraro, 1982).

Whitney, J.D., A. Elezaby, W.S. Castle, T.A. Wheaton, and R.C. Littell. 1991. Citrus tree spacing effects on soil water use, root density, and fruit yield. Trans. Amer. Soc. Agr. Eng. 34: 129-134.

Whitney, J.D., T.A. Wheaton, W.S. Castle, and D.P.H. Tucker. 1994. Optimizing orange grove factors for fruit production and harvesting. Trans. Amer. Soc. Agr. Eng. 37:365-371. 